\title{
Ikusgai-eremu elektromagnetiko osoan zehar igorpen sintonizagarria duten BODIPY laser-koloratzaileak
}

\author{
(Tunable emission from BODIPY laser dyes spanning \\ the whole visible region of the electromagnetic spectrum)
}

\author{
Edurne Avellanal-Zaballa, Ixone Esnal, Jorge Bañuelos* \\ Kimika Fisiko Saila, Zientzia eta Teknologia Fakultatea (UPV/EHU), \\ 644 PK, 48080 Bilbao \\ * jorge.banuelos@ehu.es
}

DOI: $10.1387 /$ ekaia.17771

Laburpena: Lan honetan, molekula-egiturak BODIPY deritzen koloratzaileen propietate fotofisikoetan duen eragina aztertzen da, gehienbat alde ikusgai gorritik urdinera laser sintonizagarrien ingurune aktiboa garatzeko. BODIPYaren ordezkapen-patroiaren arabera propietate espektroskopikoak modula eta optimiza daitezke. Horrela, BODIPYaren oinarrizko kromoforoa abiapuntutzat hartuta (absortzio/igorpen eremu ikusgai berde/horian) aldaketak egin dira egitura molekularrean banda espektralak lerrokatzeko, bai eremu urdinera (heteroatomoak meso posizioan sartuz), bai eremu gorrira ( $\pi$ sistema deslokalizatua hedatuz). Ondorioz, koloratzaile komertzialekin konparatuz gero, eremu espektral ikusgai osoa betetzen duten BODIPY koloratzaile berriak garatu dira, propietate fotofisiko eta laser hobetuekin.

Hitz gakoak: laser-koloratzaileak, propietate fotofisikoak, igorpen sintonizagarria.

\begin{abstract}
The herein reported work deals with the photophysical signatures of the dyes known as BODIPY. In particular, it is focused on the molecular structure impact towards the development of active media for tunable dye lasers from the blue to the red edge of the visible region. The spectroscopic properties of BODIPYs can be finely modulated and improved just changing the substitution pattern. Thus, taking as starting point the simplest core (absorption/emission at the green/yellow visible region) and after suitable chemical modifications of the backbone, its spectral bands can be deeply shifted to the blue (heteroatoms at meso position) as well as to the red-edge (extended $\pi$-system). Therefore, novel BODIPY dyes covering the whole visible spectral region have been developed with improved photophysical and laser performance with regard to the comercially available dyes.
\end{abstract}

Keywords: dye lasers, photophysical signatures, tunable emission. 


\section{SARRERA}

Azken urteotan fluoreszenteak diren koloratzaile organikoen erabilpena biozientzietan zein fotonikan, batez ere, nabarmenki areagotu da. Kromoforo hauen arrakasta sintesi organikoan [1] eta bereizmen handiko teknika espektroskopikoetan [2] izandako aurrerapausoei esker sustatu da. Esaterako, fluoreszentzia-irudiekin erlazionatutako tekniken aurrerapen teknologikoak direla eta, koloratzaileak markatzaile fluoreszente modura asko erabiltzen dira (1. irudia) [3]. Era berean, azkenengo urteetan, koloratzaileak laser (Ligth Amplification by Stimulated Emission of Radiation) arloan erabili ohi dira (2. irudia) [4]. Orokorrean, laser-erradiazioa igorpen koherentea (espaziala zein denborazkoa) eta monokromatikoa (uhin-luzera konkretu batean lan egiten duena) da, eta izugarrizko potentziak lortzeko gaitasuna aurkezten du. Ohiko laserretan igorpena oso estua (ia lerro bakarra, hots, monokromatikoa goian aipatzen den bezala) da, eta koloratzaileetan, aldiz, igorpena banda bat da. Horri esker, laserrak igorpenean izan dezakeen uhin-luzeraren tartea zabala da (sintonizagarriak) eta pultsu ultralaburrak (femtosegundoak) sor daitezke [5].

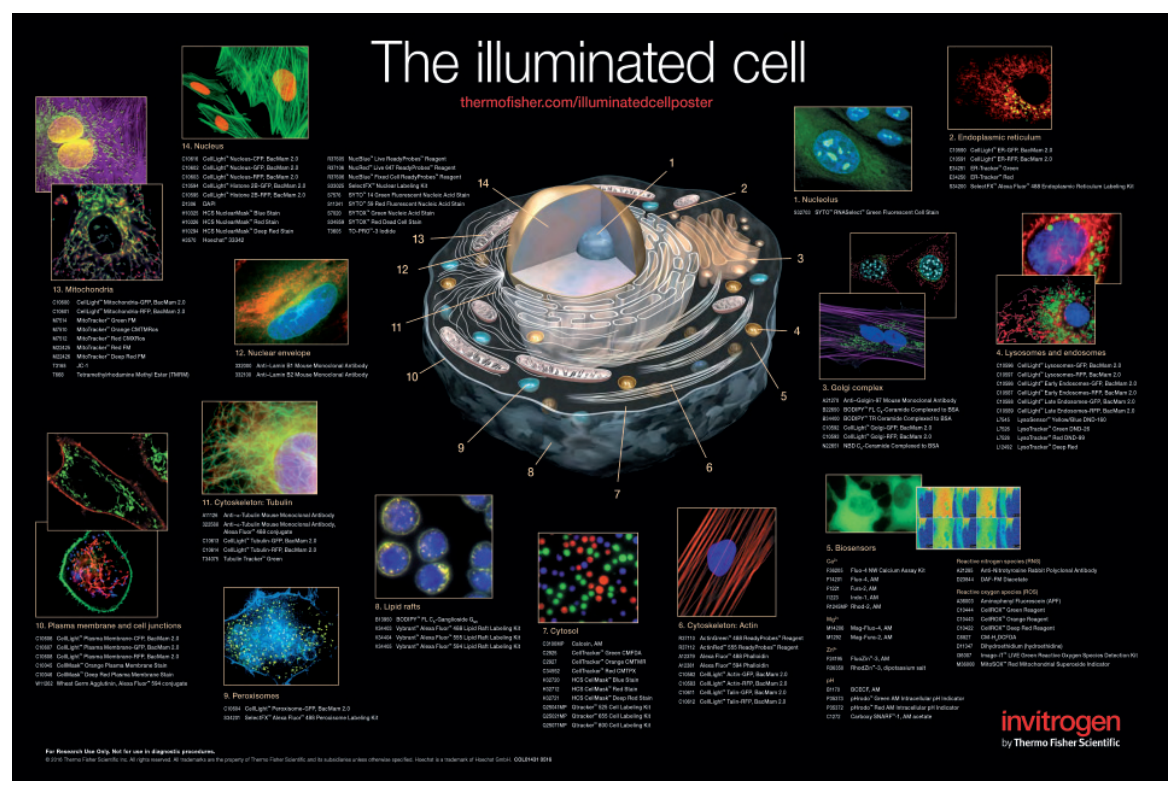

1. irudia. Lortutako zelularen irudiak markatzaile organiko fluoreszenteak erabiliz (ThermoFisher ${ }^{1}$ webgunetik).

\footnotetext{
1 https://www.thermofisher.com/es/es/home/references/newsletters-and-journals/ bioprobes-journal-of-cell-biology-applications/bioprobes-73.
} 
Fotofisikaren ikuspuntutik, molekula organikoek baldintza batzuk bete behar dituzte laser-koloratzailetzat hartzeko, laser-igorpena lortzeko dentsitate optiko altuak behar baitira [6]: (i) absortzio- eta igorpen-banda sendoak izatea, ponpaketaren erradiazioa eraginkortasunez xurgatzeko eta suspertutako igorpenaren anplifikazioa errazteko; (ii) egonkortasun kimiko, termoegonkortasun eta fotoegonkortasun altuak izatea onuragarria da, «ingurune-aktiboa» iraunkorra izan dadin.

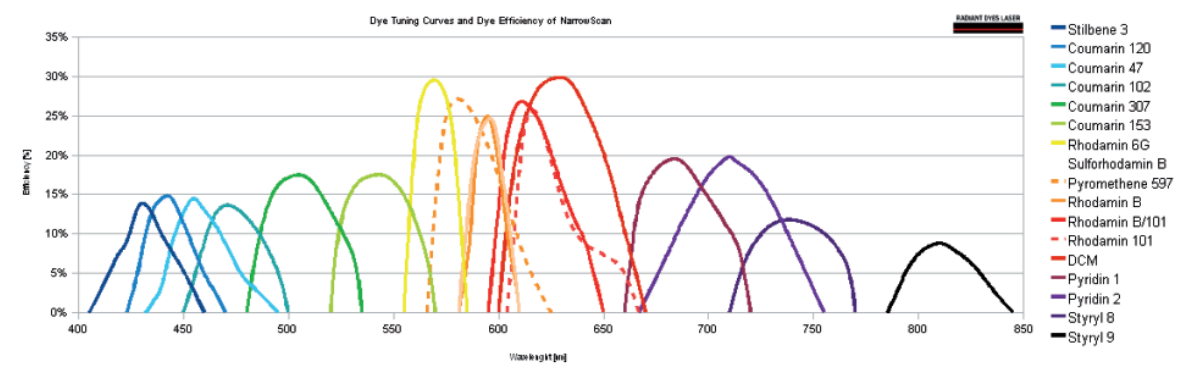

2. irudia. Hainbat laser-koloratzaileen bandak eremu ikusgaian zehar (Radiant Dyes webgunetik ${ }^{2}$.

Hori dela eta, propietate fotofisiko hobeak dituzten koloratzaile fluoreszente berrien garapena sustatu da, bai molekulen egitura aldatuz, bai koloratzaile familia berriak diseinatuz ere. Gaur egun, hainbat molekula organiko daude eremu ikusgaian zehar laser sintonizagarrien «ingurune-aktibo» modura joka dezaketenak (2. irudia). Laser-koloratzaile komertzialen familia desberdinen artean, ondorengoak azpimarratu behar dira (3. irudia): kumarinak, xantenoaren deribatuak (errodaminak edo fluoreszeina) eta oxazinak (Nilo urdina edo bioleta kresiloa).

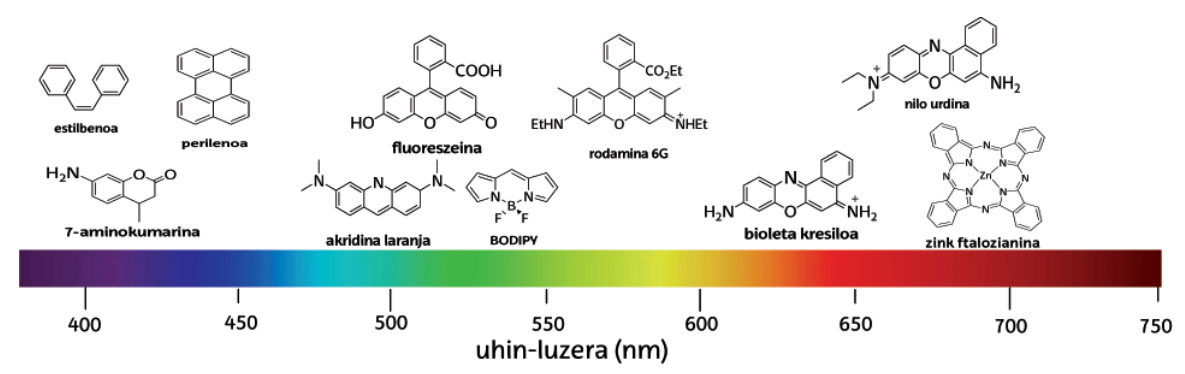

3. irudia. Hainbat laser-koloratzaileren egiturak.

2 http://www radiant-dyes.com/index.php/products/laser-dyes 
Kromoforo berrien etengabeko bilaketaren ondorioz, 4,4-difluoro-4bora-3a, 4a-diaza-s-indaceno (boro-dipirrometeno deritzenak edo laburki BODIPY, 4. irudia) koloratzaileen familia berria lortu zen [7]. Izatez, gaur egun, seguru asko laser sintonizagarrien ingurune-aktibo erabilienetarikoak dira, eta euren laser-portaera ezin hobeagatik erreferentzia-sistematzat hartu dira [8]. Aurreko baldintzak betetzeaz gain, BODIPYen abantaila nagusienetarikoa nukleo kromoforikoaren aldakortasun kimikoan datza [9]. Horrela, hainbat bide sintetikori jarraituz, boro diaza-indazenoaren egitura erabat alda daiteke selektiboki posizio zehatzetan eta talde funtzional ugari erabiliz (4. irudia). Izan ere, kimika organikorako BODIPYei «El Dorado» esaten diete [10]. Erreaktibitate kimiko horrek kromoforoan mota askotako hainbat talde funtzional txertatzea ahalbidetzen du. Era berean, koloratzailearen propietate espektroskopikoak modula daitezke (esaterako, banda espektralak borondatez desplazatzea) eta prozesu fotofisiko berriak eragin daitezke (transferentzia elektronikoa edo energia-trukea) [11]. Beste era batera esanda, BODIPYek kameleoi izaera erakusten dute; izan ere, zentzuzko diseinu molekularraren ostean, eskakizun desberdinetara egokitzen dira. Hori dela eta, gaur egun BODIPYak laserretan ez ezik, fotonikaren (gailu fotovoltaikoetan eguzki-argitik elektrizitatea ekoizteko) [12], biofotonikaren (katioien sentsore [13] eta zuntza fluoreszenteak [14]) edo biomedikuntzaren (oxigeno singletearen fotosortzaileak minbizia sendatzeko terapia fotodinamikoaren bidez) [15] arlo desberdinetan ere arrakastaz erabiltzen dira.

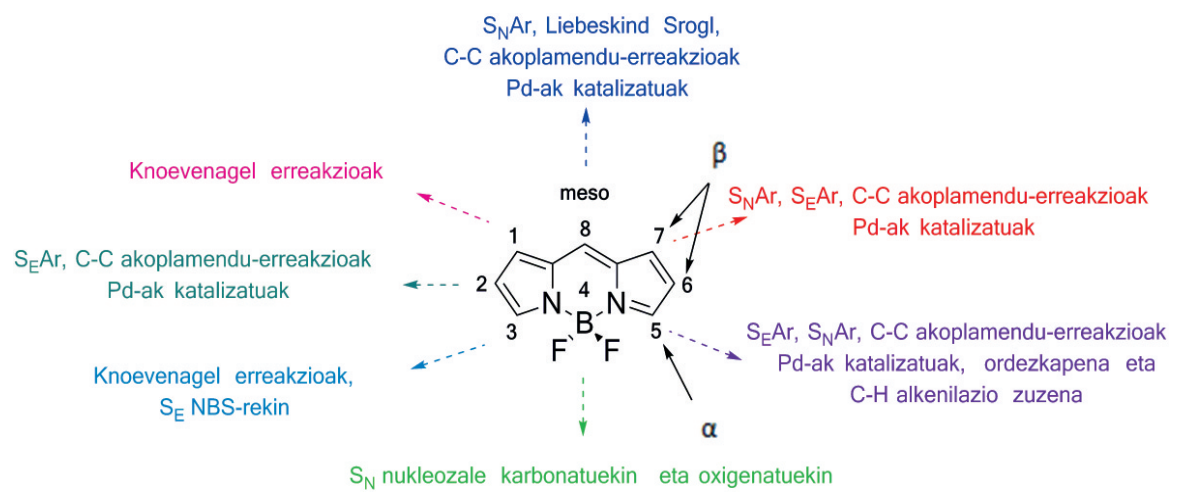

4. irudia. BODIPY nukleoaren erreaktibotasuna.

BODIPYek aurkezten dituzten aukera sintetikoez baliatuz, kromoforoaren ezaugarri fotofisikoak kontrolpean modulatzeko molekula-egitura optimizatu egin da talde funtzional aproposak erabiliz. Hain zuzen ere, helburu nagusia banda espektralen posizioa modulatzea izan da. Horretarako, eremu berde-horitik (BODIPYen ohiko igorpen-eremua) abiatu da 
eremu ikusgai urdinera, heteroatomoak meso posizioan sartuz, zein eremu gorrirako, $\alpha$ eta $\beta$ posizio pirrolikoetan zehar talde aromatikoen bidez zianina sistema konjokatua hedatuz, bilatzen den desplazamendu espektrala lortzeko (5. irudia). Modu horretan, eremu ikusgai osoan fluoreszentzia eta egonkortasun altuko laser-koloratzaileak lortu nahi dira. Lan honetan, Eduardo Peña irakaslearekin (Guanajuato Unibertsitatea, Mexikon) batera garatutako BODIPY berrien ezaugarri fotofisikoak eta mekanokuantikoak sakonki aztertu dira, molekula-egituran eragindako aldaketak bereziki aztertuz. Batez ere, ordezkatzaileen eraginean arreta jarri da, banda espektralen posizioa eta ahalmen fluoreszentea (hau da, egoera kitzikatuan prozesu erradiatzaileen eta ez-erradiatzaileen artean dagoen lehian) aztertuz. Izan ere, fotofisika ezagutzea eta ulertzea funtsezkoa da, bai laser portaera azaltzeko, bai hobetutako egitura berrien diseinu molekularra bideratzeko.

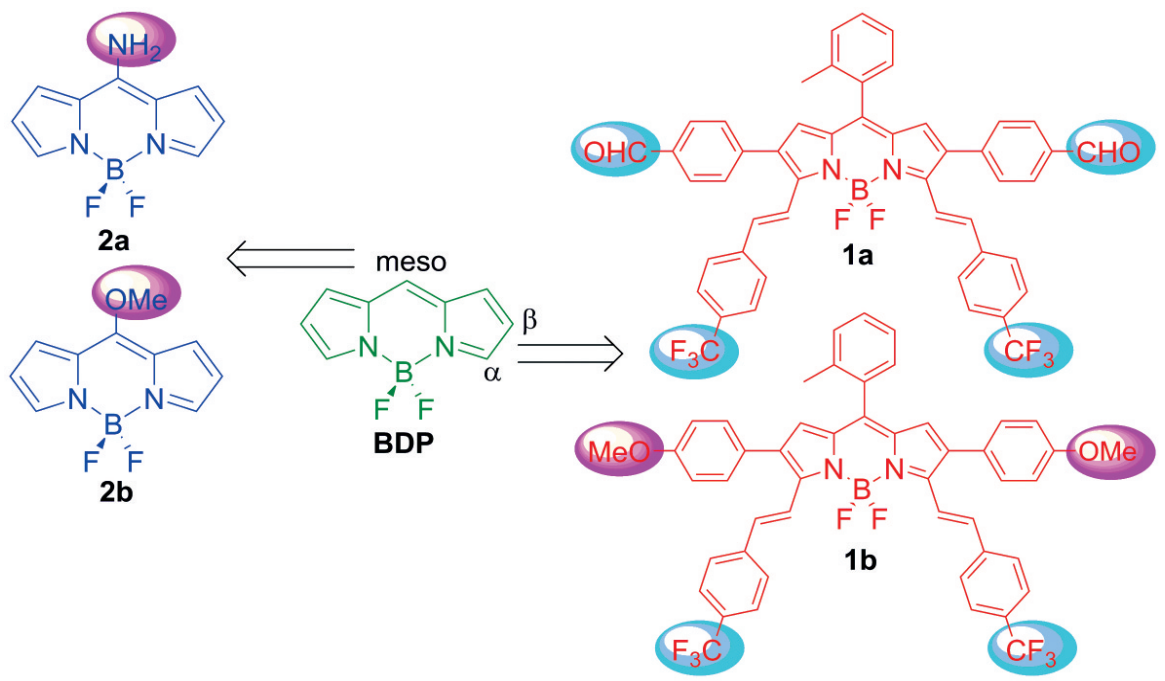

5. irudia. Aztertu diren BODIPY koloratzaileen molekula-egiturak. Talde elektroi-emaileak morez eta -hartzaileak zianez adierazi dira.

\section{MATERIALAK ETA TEKNIKA ESPEKTROSKOPIKOAK}

\subsection{Koloratzaileak eta laginen prestaketa}

BODIPY koloratzaileak sintesi organikoan espezializatua den Eduardo Peña irakaslearen (Guanajuato Unibertsitatea, Mexiko) ikerkuntza-taldeak eman zizkigun (sintesiaren xehetasunak dagoeneko argitaratuta daude; BDP eta 2a [16], 2b [17] eta $\mathbf{1 a - 1 b ~ [ 1 8 ] ) . ~ H a u e n ~ p r o p i e t a t e ~ f o t o f i s i k o e n ~}$ neurketak disoluzio diluituetan $\left(2 \cdot 10^{-6} \mathrm{M}\right)$ egin ziren. Azetonan prestatu- 
tako hasierako disoluzio kontzentratu batetik $\left(10^{-3} \mathrm{M}\right)$ abiatuz, eta azetonadisolbatzailearen kantitate egokia huts-sistemaren bidez lurrundu ondoren, dagokion koloratzailearen kontzentrazioa prestatu zen aukeratutako disolbatzailean.

\subsection{Teknika esperimentalak}

Absortzio ultramore-ikusgaiko (Varian Cary 4E modeloa) eta igorpenfluoreszenteko (FLSP920 modeloko Edinburgh Instruments) espektrofotometroak erabili ziren, $1 \mathrm{~cm}$-ko bide optikoa duen kuartzozko upelatxoa erabiliz. Fluoreszentziaren etekin kuantikoak $(\phi)$ lortzeko erreferentzia gisa koloratzaile komertzial egokiak erabili ziren ${ }^{3}$. Fluoreszentziaren desaktibazio-kurbak erregistratzeko aurreko erabilera anitzeko FLSP920 tresna erabili zen denborarekin korrelazioa duen fotoi-kontagailu kuantikoa teknikaren bidez (TC-SPC, Time-Correlated Single Photon Counting). Laginaren kitzikapena laser pultsatu (40 ps) eta sintonizagarrien bidez egin zen. Doitze esponentzialaren bitartez, zuzen bakoitzaren maldatik erdibizitzadenbora $(\tau)$ determinatu zen. Doiketa ontzat emateko chi karratuaren parametro estatistikoaren eta hondarren banaketaren analisian oinarritu zen. Laser-neurketak Inmaculada Garcia Moreno irakaslearen (CSIC, Madrid) ikerkuntza-taldean egin ziren.

\subsection{Metodo konputazionalak}

Oinarrizko egoeraren geometriaren optimizazioa dentsitate funtzionalaren teorian (DFT, Density Functional Theory) oinarritzen den metodoa erabiliz kalkulatu zen, B3LYP funtzionala erabiliz, hain zuzen ere. Bestalde, lehenengo egoera kitzikatuaren optimizazioa egiteko, ab initio CIS (Configuration Interaction Singles) metodoaren bitartez energia minimizatu zen. Egoera biak optimizatzeko, balentzia bikoitzeko 6-31G base-sistema erabili zen. Geometria benetako energia minimotzat hartu zen dagokion maiztasun-analisiak balio negatiborik aurkeztu ez zuenean. Karga elektronikoen banaketa CHelpG metodoaren bidez lortu zen. Absortzio-espektroaren trantsizio elektroniko bertikala (Franck-Condon) Time Dependent (TDB3LYP) metodoaren bitartez eta aurreko base berdina erabiliz kalkulatu zen. Aurreko kalkulu guztietan disolbatzailearen eragina kontuan hartu zen Polarizable Continuum Model (PCM) teoria erabiliz non konstante dielektrikoaren arabera disolbatzailea ingurune jarraitu bezala deskribatzen den. Kalkulu guztiak GAUSSIAN 09 programan gauzatu ziren, UPV/EHUko SGI/IZO-SGIker zerbitzuak daukan «ARINA» kluster informatikoari esker .

\footnotetext{
${ }^{3} \mathrm{http} / / \mathrm{www}$.horiba.com/fileadmin/uploads/Scientific/Documents/Fluorescence/ quantumyieldstrad.pdf
} 


\section{EMAITZAK ETA EZTABAIDA}

\subsection{BODIPYaren egitura eta fotofisika orokorra}

Koloratzaile berrien propietate fotofisikoak aztertu baino lehen, BODIPYaren oinarrizko egitura eta ezaugarri fotofisiko azpimarragarrienak laburki azaltzea komenigarria da. Horretarako, indazeno nukleo sinpleena (BDP, 5. irudian) abiapuntu modura hartzen da. Oinarrizko molekula-egitura metileno talde baten bidez elkarturiko bi pirrolez osatzen da, horrela $\pi$ dentsitate elektronikoa konjokatzen da eta zianina ziklikoa eratzen da (4. irudia). Bestalde, $\mathrm{BF}_{2}$ zubiak deslokalizazio elektronikoan parte hartzen ez duen arren, egitura molekularraren zurruntasuna ahalbidetzen du. Karga-banaketaren simulazioak iragartzen duenez, pirrolen arteko banaketa simetrikoa da eta boro atomoan karga positibo altua lokalizatzen da; karga negatiboa, aldiz, nitrogeno eta fluor atomo elektronegatiboen artean banatzen da eta azken lotura hauek ionikoak dira (6. irudia). Izan ere, potentzial elektrostatikoaren mapan fluor atomoen inguruan dentsitate elektroniko negatibo handia lokalizatzen da (gorriz) eta karga positiboa (urdinez) meso posizioaren inguruan dago. Beraz, momentu dipolar elektrikoa molekularen ardatz molekularrik txikienean zehar orientatzen da (5.1 Debye).

a)
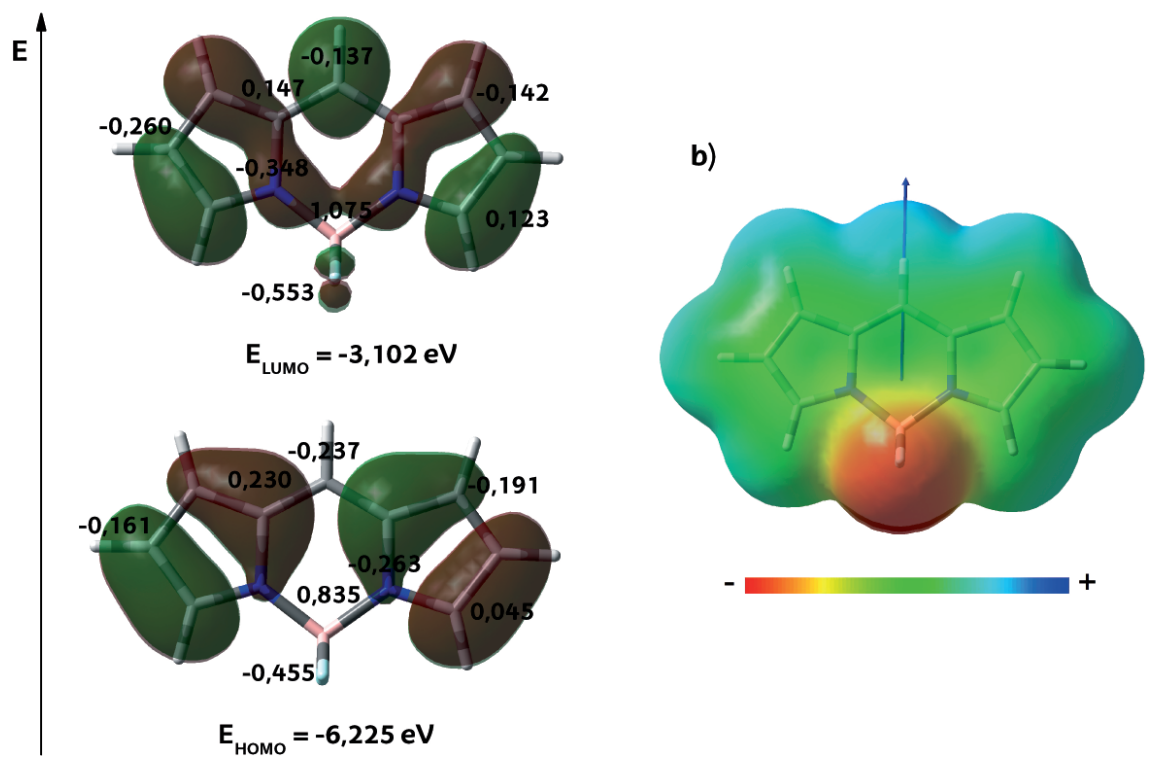

6. irudia. a) HOMO eta LUMO orbital molekularren dentsitate elektronikoen mapak, BDParen CHelpg karga partzialekin batera (atomo simetrikoen kargak ez dira adierazten). b) Potentzial elektrostatikoaren mapa (gorriz karga negatiboa eta urdinez positiboa) eta momentu dipolarraren bektorea. 
BDPek xurgapen- eta igorpen-banda intentsuak azaltzen dituzte espektroko eremu ikusgaiaren erdialdean (7. irudia). BDParen xurgapen-espektroan $500 \mathrm{~nm}$ inguruan kokatzen den banda ahaltsua $\left(\varepsilon_{\max } \sim 7 \cdot 10^{4} \mathrm{M}^{-1} \mathrm{zm}^{-1}\right)$ nagusitzen da. Simulazioak iragartzen duen trantsizio elektroniko nagusia HOMO (Highest Occupied Molecular Orbital) egoeratik LUMO (Lowest Occupied Molecular Orbital) egoeraraino gertatzen den elektroi baten jauziaren ondorioz da (hau da, $S_{0} \rightarrow S_{1}$ trantsizioari dagokiona, ikusi Jablonski diagrama 7a. irudian). HOMOtik LUMOra dentsitate elektronikoan aldaketa gertatzen da (6. irudia). Izan ere, HOMOan dentsitate elektronikoa pirroletan lokalizatzen da, eta LUMOan, aldiz, erdiko eraztunean (meso posizioan gehien bat) aurkitzen da. Horregatik, meso posizioa oso sentikorra da ordezkatzailearen arabera. Eremu ultramorean energia handiagoko trantsizioak agertzen dira, eta banda hauek ahulak eta zabalak dira.

Bestetik, fluoreszentzia-banda $510 \mathrm{~nm}$ inguruan kokatzen da (7. irudia), absortzio-bandatik gertu. Simulazioak egituraren zurruntasunagatik kitzikapenaren ondorengo berrantolaketa geometrikoa baxua dela iragartzen du. Gainera, kitzikapen- eta absortzio-espektroak bat datoz (7. irudia). BDParen fluoreszentziaren etekin kuantikoak \% 90 baino handiagoak dira eta erdibizitza-denbora $6 \mathrm{~ns}$ ingurukoa. Izan ere, molekula-egiturak desaktibazio ez-erradiatzaileen probabilitatea baxua dela ziurtatzen du. Alde batetik, $\mathrm{BF}_{2}$ loturak ezartzen duen zurruntasunari esker egitura malgutasunarekin erlazionatutako barne-konbertsio prozesuak murrizten direlako. Beste aldetik, zubi honek deslokalizazioan parte hartzen ez duenez, $\pi$ sistema ez da ziklikoa izango (kuasi-aromatikoa) [19] eta spin-orbita akoplamenduak txikiagotzen dira, eta sistemen arteko gurutzapenaren probabilitatea
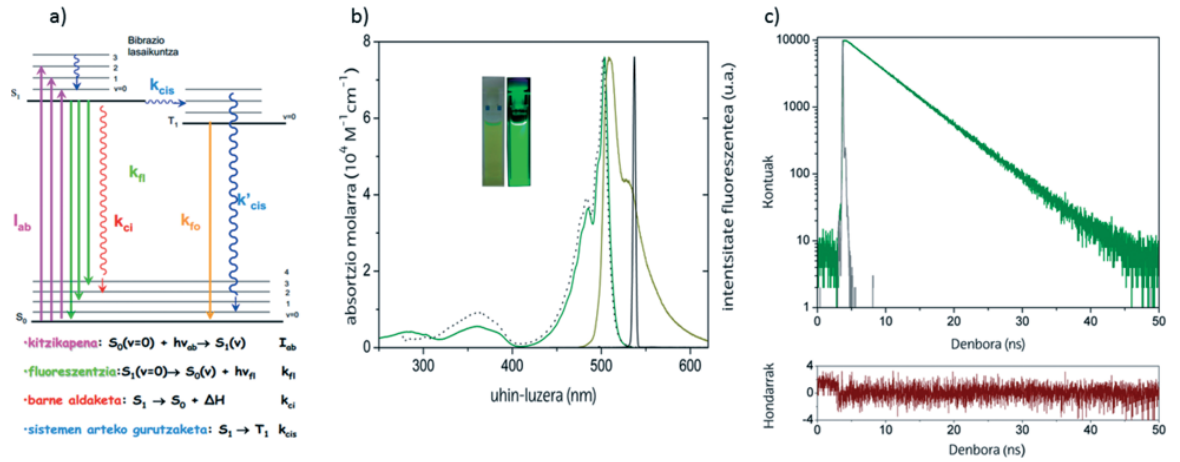

7. irudia. a) Jablonski diagrama. b) BDParen absortzio ultramore-ikusgai (berde), fluoreszentzia (hori iluna), kitzikapen- (puntu-lerroa) eta laser- (beltza) -espektro normalizatuak (inguruneko argiaz eta argi ultramorez egindako argazkiak ere txertatu dira). c) Desaktibazio-kurba, dagokion hondarren banaketarekin batera. 
murrizten da (ikusi Jablonksi diagrama 7a. irudian prozesu hauek igorpen fluoreszentearekin duten lehia behatzeko). Orokorrean, aurreko propietate espektroskopikoak ez dira aldatzen, nahiz eta ingurunearen ezaugarriak aldatu, soilik lerrokatze hipsokromiko txikiak (5 $\mathrm{nm}$ inguruko uhin-luzera baxuetarako desplazamenduak) disolbatzailearen polaritatea handitzean [6].

Ezaugarri fotofisiko honen ondorioz, laser-igorpen banda sendoa lortzen da (eraginkortasuna \% 50 inguru), $530-545 \mathrm{~nm}$ tartean sintonizagarria dena eta 50.000 pultsu ostean iraunkorra izaten jarraitzen duena.

\subsection{BODIPY gorriak}

Kontuan hartuta goian aipatutako BODIPYen jarrera optimoak laser bezala, hurrengo pausoa eremu ikusgaiko bi ertzetara eramatea da, baina kontrolpean eta eraginkortasuna eta fotoegonkortasuna mantenduz. Alde ikusgai gorrian edo infragorri hurbilean (NIR) igortzen duten fluoroforoak arreta handia jasotzen ari dira, batez ere biomedikuntzan eta biofotonikan erradiazio honen ahalmenagatik ehunetan zehar sakonki barneratzeko [20]. Hala ere, komertzialki eskuragarri dauden NIR koloratzaileek (adibidez oxazinak, 3. irudia) fluoreszentzia-etekin kuantiko baxuak eta, batez ere, fotoegonkortasun txikia dituzte. Beraz, luzaro erradiazio ahaltsua jasateko BODIPYen sendotasun eta ahalmen fluoreszente altuak beharrezkoak dira. Kromoforoak aurkezten duen aldakortasun sintetikoaz baliatuz, $\pi$ sistema hedatzeko talde aromatikoak txertatu ziren. Lerrokatze batokromikoa indartzeko, talde elektroi-emaile eta -hartzaileak ere txertatu ziren. Horregatik, lan honetan aztertzen diren BODIPY gorriek nukleoaren meso posizioan talde neutroa eta zurruna (orto-metilfeniloa) daramate, $\alpha$ posizioetan talde hartzaileak (para-trifluorometilestiriloa) eta, $\beta$ posizioetan, ordea, talde hartzaileak (1a, para-formilfeniloa) edo emaileak (1b, para-metoxifeniloa) (5. irudia)

Erabateko funtzionalizazioaren ondorioz gorriranzko lerrokatze espektral nabaria lortu da (150 nm inguru gehitu BDParekin alderatuz), absortzio-probabilitatearen handiagotzearekin batera $\left(>10^{5} \mathrm{M}^{-1} \mathrm{~cm}^{-1}\right), \alpha$ eta $\beta$ posizioetan zehar $\pi$ sistemaren hedapena dela eta (8. irudia). Aipatu behar da meso posizioan dagoen feniloak ez daukala kromoforoarekin elkarrekintza erresonanterik orto-metiloak eragindako eragozpen esterikoagatik (8fenil eraztuna $80^{\circ}$ biratuta dago, $8 \mathrm{~b}$. irudian). Beste aldetik, kromoforoaren eta kate aromatikoen arteko elkarrekintzak ( $\alpha$-estiriloen artekoa gehien bat) eremu ultramorean absortzio-intentsitatearen handipena eragiten du (350 nm inguruan, 8. irudia). Absortzio-banda sendo horrek oso abantaila garrantzitsua dakar laser-aplikazioaren ikuspuntutik. Izan ere, eremu gorriko koloratzaileak ponpatzea ez da gauza hutsala, 532 eta $355 \mathrm{~nm}$-tan (Nd-YAG bidez ponpatzeko ohiko uhin-luzerak) argiaren absortzioa baxua 
a)

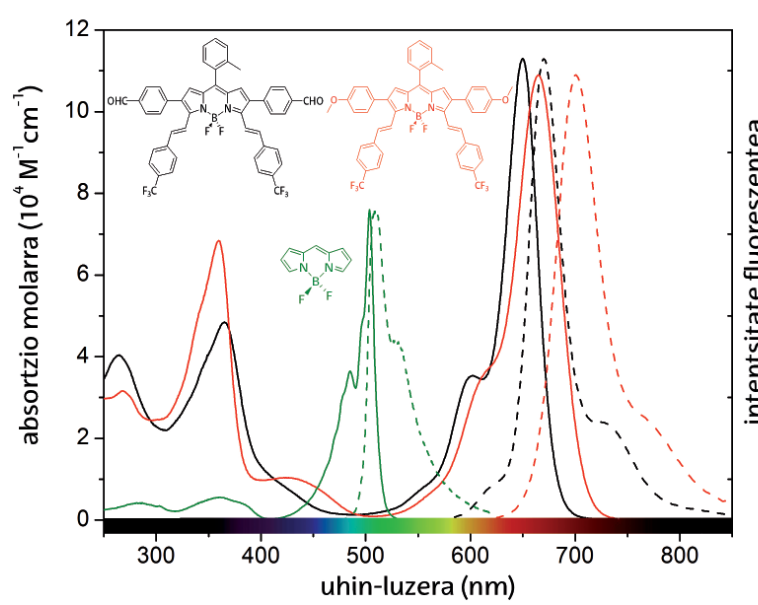

b)

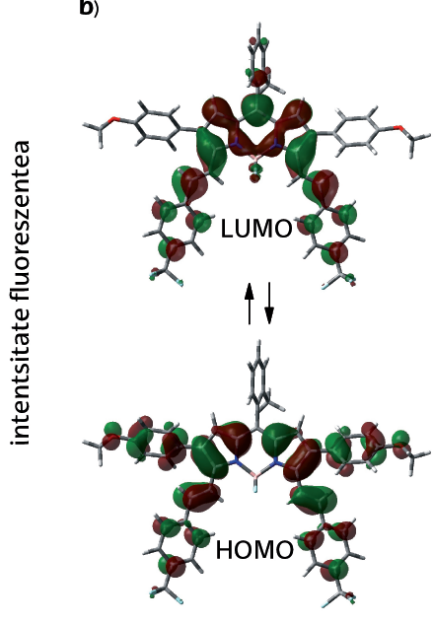

8. irudia. a) 1a eta 1b BODIPY gorrien absortzio- eta fluoreszentzia- (lerro etenek) -espektro normalizatuak. b) Orbital molekularren (HOMO eta LUMO) dentsitate elektronikoaren mapak.

baita; beraz, kontzentrazio oso altuak beharrezkoak dira. Halere, BODIPY berri hauek $355 \mathrm{~nm}$-tan aurkezten duten absortzio sendoari esker, ponpaketa errazten da eta laser-seinalea lor daiteke, dentsitate optiko txikiagoak erabiliz.

Hala ere, bi BODIPY gorri hauen ezaugarri fluoreszenteak nahiko ezberdinak dira. Alde batetik, 1a-k etekin kuantiko fluoreszente onak erakusten ditu (ia \% 90) $670 \mathrm{~nm}$ inguru, nahiz eta disolbatzailearen polaritatea handitu (1. Taula). Beste aldetik, 1b-k (metoxi formiloaren ordez) igorpen gorriagoa erakusten du (705 nm-tan inguru, 8. irudia), baina etekin fluoreszente baxuagoak, batez ere ingurune polarretan (soilik \% 13, 1. Taula) non erdibizitza-denbora azkarragoak (4,25 ns-tik 1,20 ns-ra) ere behatzen diren. Gainera, disolbatzailearen polaritatearekin, igorpen-bandaren lerrakuntza batokromikoki eragiten da (uhin-luzera handiagoetara), absortzioan ohiko joera hipsokromikoa iragazten den arren. Beraz, metoxi talde elektroiemaileak alde gorrirako banda espektralen lerrokatzea indartzen du, baina era berean, kitzikapenaren ondorioz prozesu ez-erradiatzaile baten agerpena bultzatzen du. Egitura berberean, talde hartzaile (trifluorometiloak) eta emaile (metoxiak) ahaltsuak txertatzean, karga-transferentzia prozesu intramolekularrak (Intramolecular Charge Transfer, ICT) suspertzen dira egoera kitzikatuan. Hau da, 1b koloratzailean karga-transferentzia metoxi emailetik trifluorometil hartzailera bultzatzen da. Aldiz, 1a-n ez dagoenez talde emailerik (baizik eta formiloa hartzailea dena), karga-transferentzia ez dago hain egonkortua eta egoera kitzikatu berri hori ez da sortzen. 


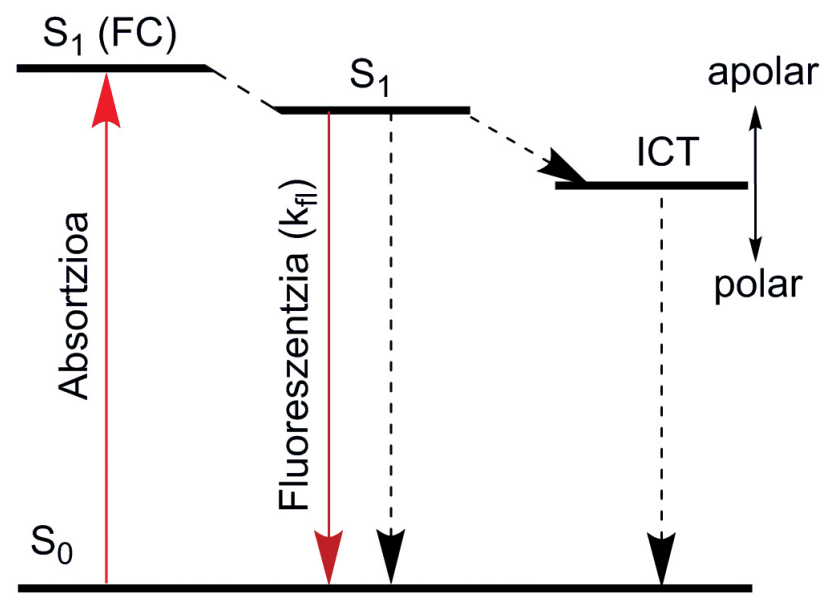

9. irudia. 1b koloratzailean proposatutako maila energetikoen antolaketa (lerro etenek argirik igortzen ez duten prozesuak adierazten dituzte).

ICT egoera fotoinduzitua $\mathbf{1 b}-\mathrm{n}$ ez da fluoreszentea (ez dira igorpen berririk behatzen) eta igorlea den fluoreszentzia egoera desaktibatzen du, batez ere disolbatzaile polarretan (9. irudia). Izan ere, sortutako karga banaketagatik (emailea karga positiboarekin geratzen da eta hartzaileak karga negatiboa hartzen du), ICT oso egoera polarra da eta bereziki egonkortzen da disolbatzaile polarretan. Beraz, prozesu honek eragindako desaktibazio ez-erradiatzailea areagotzen da (egoera honen populazio faboratuta dago ikuspuntu termodinamikotik), eta ondorioz, fluoreszentzia gehiago murrizten da metanolean ziklohexanoan baino (1. Taula).

1. taula. BODIPY gorrien (1a eta 1b) propietate fotofisikoak polaritate ezberdineko disolbatzaileetan (ziklohexanoa apolarra eta metanola polarra): absortzio $\left(\lambda_{\mathrm{ab}}\right)$ eta fluoreszentzia $\left(\lambda_{\mathrm{fl}}\right)$ uhin-luzera maximoak, absortzio molar maximoa $\left(\varepsilon_{\max }\right)$, fluoreszentzia-etekin kuantikoa $(\phi)$ eta erdibizitza-denbora $(\tau)$.

\begin{tabular}{c|c|ccccc}
\hline \multicolumn{2}{c|}{} & $\begin{array}{c}\lambda_{\mathrm{ab}} \\
(\mathrm{nm})\end{array}$ & $\begin{array}{c}\varepsilon_{\max } \\
\left(10^{4}\right. \\
\left.\mathrm{M}^{-1} \mathrm{zm}^{-1}\right)\end{array}$ & $\begin{array}{c}\lambda_{\mathrm{fl}} \\
(\mathrm{nm})\end{array}$ & $\mathrm{f}$ & $\begin{array}{c}\tau \\
(\mathrm{ns})\end{array}$ \\
\hline \multirow{2}{*}{ 1a } & z-hex & 650,0 & 11,3 & 670,0 & 0,87 & 4,61 \\
& $\mathrm{MeOH}$ & 644,0 & 10,4 & 668,0 & 0,73 & 4,36 \\
\hline \multirow{2}{*}{ 1b } & z-hex & 665,0 & 10,9 & 701,0 & 0,61 & 4,25 \\
& $\mathrm{MeOH}$ & 657,5 & 8,9 & 708,0 & 0,13 & 1,20 \\
\hline
\end{tabular}

z-hex: ziklohexanoa, MeOH: metanola. 
Ezaugarri fotofisiko hauen ondorioz, 1a BODIPYak (non ICT prozesua sortzeko aukera arbuiagarria den) $700 \mathrm{~nm}$ aldera laser-seinale eraginkorra (\% 60 ingurukoa) eta fotoegonkortasun altua (\% 10050.000 pultsu ondoren) aurkezten du. Gainera, $355 \mathrm{~nm}$-tan (Nd:YAG hirugarren harmonikoa) erraz ponpatu ahal denez, komertzialki eskuragarriak diren laser-koloratzaile gorriek baino portaera hobea eskaintzen du. 1b-n, aldiz, laser-igorpena NIR aldera bultzatzen da $(740 \mathrm{~nm})$, baina fluoreszentziarako kaltegarria den ICT prozesua dela eta, disolbatzailearen arabera eraginkortasuna $\%$ 20-40ra jaisten da. Beraz, lerrokatze batokromikoa hobetzeko karga-banaketa eragitea komenigarria da, baina ez gehiegi, laser-eraginkortasuna mugatzen delako.

\subsection{BODIPY urdinak}

Aurretik adierazi den bezala, BODIPY koloratzaileen moldagarritasun sintetikoari esker, bere igorpena eremu gorrira edo NIR aldera eraman da, sistema konjokatua hedatuz. Hala ere, kontrako lerrokatze espektrala lortzea, hots, alde urdinera, ez da hain erraza. Izan ere, eremu espektral horretan (400-500 $\mathrm{nm}$ ) igorpen mugatuta duten BODIPYen egitura analogoei buruzko ikerketak oso gutxi dira eta lortutako emaitzak ez dira onak izan [21]. Gaur egun, eremu horretan hainbat koloratzaile organiko daude (adibidez kumarinak, 3. irudia), baina igorpen-ahalmena txikia da edo egonkortasun fotokimikoa baxua da. Ezustean bilatutako BODIPY urdinak lortu ziren soilik meso posizioan heteroatomoak (nitrogeno, 2a, edo oxigeno, 2b, 5. irudia) erantsiz.

\subsection{1. meso-AminoBDP (2a)}

Hasiera batean, pentsa liteke amino taldea (elektroi-emaile ahaltsua) erresonantzian egon daitekeela BDP kromoforoarekin, eta gorriranzko lerrokatzea sorrarazi. Hala eta guztiz ere, bere presentziak meso posizioan (2a) kontrako joera sorrarazten du, hau da, lerrokatze hipsokromikoa, bereziki absortzio-espektroan (95 $\mathrm{nm}$ arte BDPrekin alderatuz, 9. irudia). Gainera, amino taldeak absortzio-probabilitatea murriztu $\left(3 \cdot 10^{4} \mathrm{M}^{-1} \mathrm{~cm}^{-1}\right.$ inguruan) eta banda zabaltzen du (10. irudia). Beste aldetik, igorpen fluoreszentea 400-430 nm inguruan oso eraginkorra da (etekin kuantikoak $>\% 90$ edozein ingurunean erdibizitza denbora $5 \mathrm{~ns}$ inguru izanik, 2. Taula).

Simulazio teorikoak ere BDPan meso-aminoa eranstean espektroa energia handiagoetara desplazatzen dela iragartzen du (10. irudia). Jauzi energetikoaren handipen hori, LUMO orbitalaren energia handiagotzearen ondorioa da batez ere. Meso posizioan dentsitate elektroniko altua lokalizatzen da LUMOan; beraz, amino taldearen izaera emaileak orbital hau desegonkortzen du, eta LUMOaren energia handitzen du, HOMOarena ia aldatu barik. Dena den, simulazio teorikoak iragartzen duen lerrokatze hip- 
a)

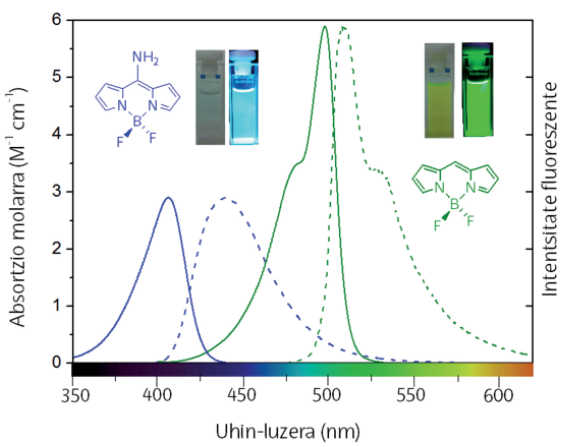

b)

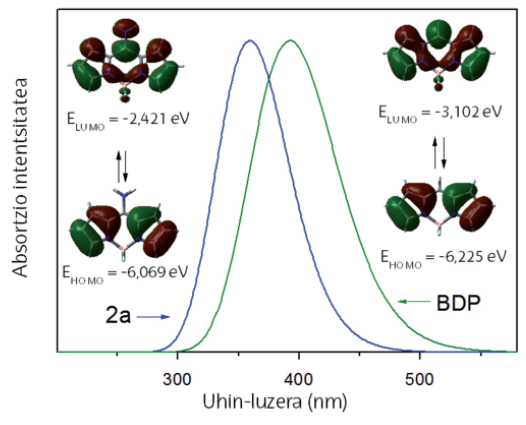

10. irudia. a) meso-aminoBDP $2 \mathbf{a}$ eta BDParen absortzio eta fluoreszentzia (lerro etenek) espektro normalizatuak. Inguruneko argian eta argi ultramorepean egindako argazkiak ere txertatzen dira. b) Absortzio-espektroen simulazioa eta deribatu bakoitzari dagozkion orbital molekularren dentsitate elektronikoen mapak.

2. taula. Meso posizioan amina primarioa ordezkatua duen BODIPY 2a vs BDParen propietate fotofisikoak, disolbatzailearen polaritatearen arabera.

\begin{tabular}{l|l|ccccc}
\hline \multicolumn{2}{l|}{} & $\begin{array}{c}\lambda_{\mathrm{ab}} \\
(\mathrm{nm})\end{array}$ & $\begin{array}{c}\varepsilon_{\max } \\
\left(10^{4} \mathrm{M}^{-1} \mathrm{zm}^{-1}\right)\end{array}$ & $\begin{array}{c}\lambda_{\mathrm{fl}} \\
(\mathrm{nm})\end{array}$ & $\mathrm{f}$ & $\begin{array}{c}\tau \\
(\mathrm{ns})\end{array}$ \\
\hline \multirow{4}{*}{ BDP } & z-hex & 503,5 & 7,6 & 510,5 & 0,96 & 6,47 \\
& MeOH & 497,0 & 5,8 & 507,0 & 0,87 & 7,33 \\
& $\mathrm{~F}_{3}$-EtOH & 497,0 & 6,1 & 505,0 & 0,86 & 8,23 \\
\hline \multirow{4}{*}{ 2a } & z-hex & 429,0 & 1,0 & 456,5 & 0,96 & 4,49 \\
& MeOH & 399,0 & 2,6 & 437,5 & 0,92 & 4,39 \\
& $\mathrm{~F}_{3}$-EtOH & 402,5 & 2,4 & 457,5 & 0,94 & 5,86 \\
\hline
\end{tabular}

z-hex: ziklohexanoa, $\mathrm{MeOH}$ : metanola, $\mathrm{F}_{3}$-EtOH: 2,2,2-trifluoroetanola.

sokromikoa esperimentala baino txikiagoa da. Beraz, eta espektroen itxura-aldaketa (zabalketa) ere kontuan hartuz, meso-aminarekiko elkarrekintza erresonanteari esker kromoforoaren deslokalizazio elektronikoa berrantolatzen dela ondorioztatzen da. Egitura erresonante berri bat (hemizianina modukoa) sortzen da, hain zuzen ere, konjokazio berri hori pirrol bakar batekin soilik posiblea baita (11. irudia). Egitura mesomeriko hori egonkortzean, banda espektralen urdineranzko desplazamendua lortzen da.

Laburbilduz, meso posizioan amina primario bat txertatuz igorpena alde urdinera arrakastaz eramaten da. Izan ere, $450 \mathrm{~nm}$ inguruan laser-seinalea 


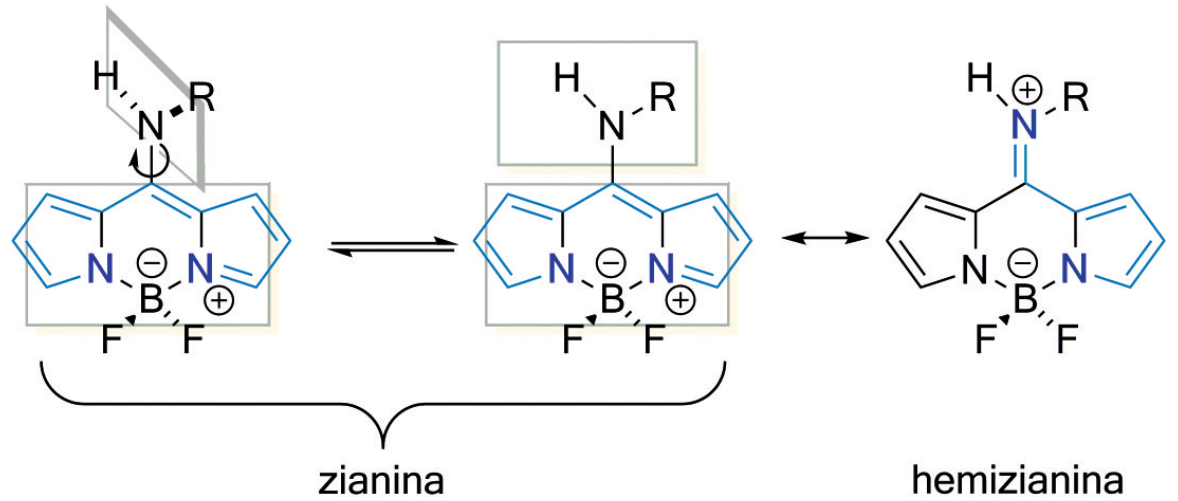

11. irudia. Meso-aminoBDParen $\pi$ sistema deslokalizatuaren egiturak (igorpenaren eragilea den katea urdinez adierazten da).

lortzen da, \% 62ko eraginkortasunarekin. Gainera, 100.000 kitzikapen-pultsu ondoren, fotoegonkortasunak \% 40 izaten jarraitzen du. Kontuan hartuz ultramorean ponpaketa oso energetikoa dela eta, hortaz, fotodegradazioa ere, bere portaera bikaina da. Are gehiago, fotoegonkortasun hau kumarina koloratzailearena baino askoz handiagoa da.

\subsection{2. meso-metoxiBDP (2b)}

Aminoak eragindako aldaketa bortitzak eta joerak ikusiz, 8 posizioan izaera emaile desberdineko atomoak txertatzea erabaki genuen, esate baterako aminoaren ordez metoxia (2b) txertatzea, lerrokatze hipsokromikoa modulatzeko. Oxigenoaren elektronegatibitatea handiagoa denez, metoxiaren izaera emailea txikiagoa da. Beraz, meso-metoxi taldeak LUMOa ere desegonkortzen du, baina amino taldeak baino gutxiago. Gainera metoxi taldearen elektroi-bikotearen eta indazenoaren arteko elkarrekintza erresonanteak, banaketa elektronikoaren berrantolaketa ere eragiten du, hala nola merozianina deritzon forma mesomeriko berriaren eraketa (12. irudia). Ondorioz, BDParekin alderatuz, 2b-an oraindik lerrokatze hipsokromikoa lortzen da (absortzioan $\sim 55 \mathrm{~nm}$ eta fluoreszentzian $\sim 20 \mathrm{~nm}, 3$. Taula vs 2. Taula), baina 8-aminoak eragindakoa baino txikiagoa (12. irudia). Are gehiago, eta $\mathbf{2 a}$ alderatuz, $\mathbf{2 b}$-an absortzio-probabilitatea handiagoa da $\left(\sim 4-6 \cdot 10^{4} \mathrm{M}^{-1} \mathrm{zm}^{-1}\right)$ eta espektroak estuagoak dira, eta BDParen ohiko sorbalda bibronikoa berreskuratzen da eta lortutako ahalmen fluoreszenteak oso onak izaten dira (\% 75 baino balio altuagoak ingurune guztietan, eta erdibizitza 6 ns inguru mantentzen da, 3. Taula). 
3. taula. Meso-metoxi taldea duen $\mathbf{2 b}$-aren propietate fotofisikoak, disolbatzailearen polaritatearen arabera.

\begin{tabular}{cccccc}
\hline & $\begin{array}{c}\lambda_{\mathrm{ab}} \\
(\mathrm{nm})\end{array}$ & $\begin{array}{c}\varepsilon_{\max } \\
\left(10^{4} \mathrm{M}^{-1} \mathrm{zm}^{-1}\right)\end{array}$ & $\begin{array}{c}\lambda_{\mathrm{fl}} \\
(\mathrm{nm})\end{array}$ & $\mathrm{f}$ & $\begin{array}{c}\tau \\
(\mathrm{ns})\end{array}$ \\
\hline z-hex & 452,0 & 6,1 & 487,0 & 0,84 & 5,41 \\
MeOH & 441,0 & 4,6 & 485,5 & 0,75 & 6,14 \\
\hline
\end{tabular}

z-hex: ziklohexanoa, MeOH: metanola.

a)

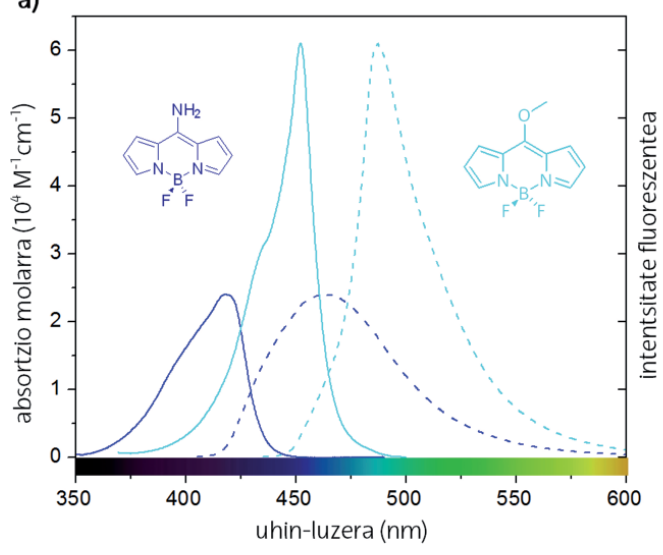

b)

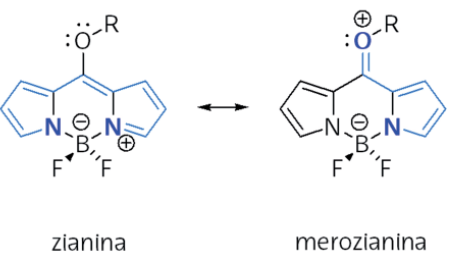

12. irudia. a) Meso-metoxiBDP 2b (zianez) eta meso-aminoBDP 2a (urdinez) erakusten dituzten absortzioaren eta fluoreszentzia-igorpenaren (lerro etenek) espektro normalizatuak. b) 2b-ren $\pi$ sistema deslokalizatuaren egiturak (igorpenaren eragile den katea urdinez adierazten da).

\section{ONDORIOAK}

Lan honetan, agerian jarri da BODIPY koloratzaileen ezaugarri espektroskopikoak biziki baina kontrolpean modula daitezkeela bere oinarrizko propietate fluoreszente distiratsuak mantenduz. Horretarako, diseinu molekularra ezinbestekoa da, hau da, ordezkatzaile aproposak aukeratu behar dira bilatzen den aldaketa fotofisikoa sorrarazteko.

BODIPYen absortzio/igorpen alde espektrala gorrira eramateko $\pi$ sistema deslokalizatua hedatzea ezinbesteko da. Horretarako, elektroi-emaile/-hartzaileak daramaten talde aromatikoak kromoforoan lotzea jokabide aproposa izan da fluoroforo gorriak lortzeko. Hala ere, kontu handiz aukeratu behar dira elektroi-emailearen/-hartzailearen sendotasuna. Horie- 
tako, bi talde ahaltsuak batera badaude, molekula-egituran koloratzaileak gorriagoak dira, baina eraginkortasun fluoreszentea galtzen da sorrarazitako kargaren banaketa dela eta. Bestetik, absortzio/igorpen alde espektrala urdinera eramateko eta fluoroforo urdin ezin hobeak garatzeko, meso posizioan elektronegatibitate ezberdineko heteroatomoak (nitrogeno eta oxigeno) txertatzea aukera erraza eta arrakastatsua izan da. Izan ere, aminarekiko eta metoxiarekiko elkarrekintza erresonanteak direla medio, sistema konjokatu berriak eta motzagoak eratzen dira (zianinatik hemi- edo merozianinara).

Ondorioz, ikusgai-espektro osoan zehar igortzen duten BODIPYan oinarritutako laser-koloratzaile optimoak lortu dira, eta bere etekin fotonikoa komertzialki eskuragarri dauden laser organikoena baino hobea da, bereziki fotoegonkortasunari dagokionez.

\section{ESKER ONAK}

Artikulu hau Eusko Jaurlaritzak emandako diru-laguntzari (IT912-16 proiektua) eta doktoregai-bekari (EAZ) esker gauzatu da. Era berean, E. Peña eta I. Garcia ikertzaileei laginen sintesiagatik eta laser neurketengatik eskertzen diegu, hurrenez hurren. Eskerrak ere UPV/EHUko SGI/ IZO-SGIker zerbitzuari «ARINA» kluster informatikoa erabiltzen uztearren.

\section{BIBLIOGRAFIA}

[1] DE MOLINER, F., KIELLAND, N., LAVILLA, R., VENDRELL, M. 2017. «Modern Synthetic Avenues for the Preparation of Functional Fluorophores». Angew. Chem. Int. Ed., 56, 3758-3769.

[2] HELL, S.W. 2015. «Nanoscopy with Focused Light». Angew. Chem. Int. $E d ., 54,8054-8066$.

[3] WEISSLEDER, R., PITTET, M.J. 2008. «Imaging in the era of molecular oncology». Nature, 452, 580-589.

[4] CHÉNAIS, S., FORGET, S. 2011. «Recent advances in solid-state organic lasers». Polym. Int., 61, 390-406.

[5] KUEHNE, A., GATHER, M. 2016. «Organic Lasers: Recent Developments on Materials, Device Geometries, and Fabrication Techniques». Chem. Rev. 116, $12823-12864$.

[6] LÓPEZ-ARBELOA, F., BAÑUELOS, J., MARTÍNEZ, V., ARBELOA, T., LÓPEZ-ARBELOA, I. 2005. «Structural, photophysical and lasing properties of pyrromethene dyes». International Reviews in Physical Chemistry, 24, 339-374. 
Ikusgai-eremu elektromagnetiko osoan zehar igorpen sintonizagarria duten BODIPY laser-koloratzaileak

[7] LOUDET, A., BURGESS, K. 2007. «BODIPY Dyes and Their Derivatives: Synthesis and Spectroscopic Properties». Chem. Rev., 107, 4891-4932.

[8] COSTElA, A., GARCÍA-MORENO, I., SASTRE, R. 2003. «Polymeric solid-state dye lasers: Recent developments». Phys. Chem. Chem. Phys., 5, 4745-4763.

[9] ULRICH, G., ZIESSEL, R., HARRIMAN, A. 2008. «The Chemistry of Fluorescent BODIPY Dyes: Versatility Unsurpassed». Angew. Chem. Int. Ed., 47, 1184-1201.

[10] ZIESSEL, R., ULRICH, G., HARRIMAN, A. 2007. «The Chemistry of BODIPY Dyes: A new El Dorado for fluorescence tools». New J. Chem., 31, 496-501.

[11] BENNISTON, A.C., COPLEY, G. 2009. «Lighting the way ahead with boron dipyrromethene (BODIPY) dyes». Phys. Chem. Chem. Phys., 11, 41244131 .

[12] BESETTE, A., HANAN, G.S. 2014. «Design, synthesis and photophysical studies of dipyrromethene-based materials: insights into their applications in organic photovoltaic devices». Chem. Soc. Rev., 43, 3342-3405.

[13] BOENS, N., LEEN, V., DEHAEN, W. 2011. «Fluorescent indicators based on BODIPY». Chem. Soc. Rev., 41, 1130-1172.

[14] KOWADA, T., MAEDA, H., KIKUCHI, K. 2015.«BODIPY-based probes for the fluorescence imaging of biomolecules in living cells». Chem. Soc. Rev., 44, 4953-.

[15] KAMKAEW, A., LIM, S.H., LEE, H.B. KIEW, L.V., CHUNG, L.Y., BURGESS, K. 2013. «BODIPY dyes in photodynamic therapy». Chem. Soc. Rev., 42, 77-88.

[16] BAÑUELOS, J., MARTIN, V., GÓMEZ-DURÁN, C.F.A., ARROYOCÓRDOBA, I.J., PEÑA-CABRERA, E., GARCÍA-MORENO, I., COSTELA, A., PÉREZ-OJEDA, M.E., ARBELOA, T., LÓPEZ-ARBELOA, I. 2011. «New 8-amino-BODIPY derivatives: surpassing laser dyes at blueedge wavelengths». Chem. Eur. J., 17, 72161-7270.

[17] FLORES-RIZO, J.O., ESNAL, I., OSORIO-MARTÍNEZ, C.A., GÓMEZDURÁN, C.F.A., BAÑUELOS, J., LÓPEZ-ARBELOA, I., PANELL, K.H., METTA-MAGAÑA, A.J., PEÑA-CABRERA, E. 2013. «8-Alkoxy- and 8-Aryloxy-BODIPYs: Straightforward fluorescent tagging of alcohols and phenols». J. Org. Chem., 78, 5867-5877.

[18] GÓMEZ-DURÁN, C.F.A., ESNAL, I., VALOIS-ESCAMILLA, I, URIASBENAVIDES, A., BAÑUELOS, J., LÓPEZ-ARBELOA, I., GARCÍAMORENO, I., PEÑA-CABRERA, E. 2016. «Near-IR BODIPY dyes à la carte - Programmed functionalization of rationally designed building blocks». Chem. Eur. J., 22, 1048-1061.

[19] PAVLOPOULOS, T.G. 2002. «Scaling of dyes lasers with improved laser dyes». Progress in Quantum Electronics, 26, 193-224. 
[20] LU, H., MACK, J., YANG, Y., SHEN, Z. 2014.«Structural modification strategies for the rational design of red/NIR region BODIPYs». Chem. Soc. Rev., 43, 4778-4823.

[21] BAÑUELOS, J., LÓPEZ-ARBELOA, F., MARTÍNEZ, V., LIRAS, M., COSTELA, A., GARCÍA-MORENO, I., LÓPEZ-AREBLOA, I. 2011. «Difluoro-boron-triaza-anthracene: a laser dye in the blue region. Theorical simulation of alternative difluoro-boron-diaza-aromatic systems». Phys. Chem. Chem. Phys., 13, 3437-3445. 